\title{
Discussion And Practice Of Production Practice Mode Based On Little Research
}

\author{
Huang Bin * \\ Instrument Science and Opto-electronics Engineering \\ HeFei University of Technology \\ HeFei, China \\ e-mail:ahhb7310168@163.com \\ * Corresponding Author
}

Wang Xiaomeng

Instrument Science and Opto-electronics Engineering

HeFei University of Technology

HeFei, China

e-mail: 1527466604@qq.com

Yi Jiajing

Instrument Science and Opto-electronics Engineering

\author{
HeFei University of Technology \\ HeFei, China \\ e-mail: a138tp@163.com
}

\begin{abstract}
In order to solve the prevailing formalism of College Students' production practice, this paper deeply analyzes the roots of unwelcome current passive production practice and puts forward an active mode of production practice from the perspective of corporate interests, which is based on little research .The mode mixes enterprise technical requirements and production practice together, which realize win-win benefit between enterprises and universities. Practice has proved that this production practice mode can not only fully mobilize the enthusiasm of the enterprises, but also can improve the effect of production practice.
\end{abstract}

Keywords-production practice; practical education; little research; active practice; win-win benefit between enterprises and universities

\section{INTRODUCTION}

Production practice is a major practical course which is an effective way for students to combine theoretical knowledge with production practice, it is a process of strengthening the students' working attitude ,engineering viewpoint, work responsibility and the sense of mission. Production practice is one of important practical teaching links of personnel training of the engineering specialty in colleges and universities and is an important part of the teaching work in colleges and universities, which plays important roles in promoting the combination of theory teaching and production practice, cultivating students' practical ability, and cultivating ability to observe and solve the problems. Opinions on comprehensively improving the quality of higher education from the

\author{
Li Chengwei \\ Instrument Science and Opto-electronics Engineering \\ HeFei University of Technology \\ HeFei, China \\ e-mail: 836277034@qq.com
}

\author{
Tao Jiayue \\ Instrument Science and Opto-electronics Engineering \\ HeFei University of Technology \\ HeFei, China \\ e-mail:1437828452@qq.com
}

ministry of education ${ }^{[1]}$ clearly put forward to strengthen the guiding ideology of practical education and to strengthen the sharing platform construction of practical training base and practical teaching, which require new student grants were first put into practical educational work and new education funds were first put into practice teaching.

Since the reform and opening up, many colleges and universities do not want to accept students' all kinds of practice activities with the reform of the enterprise market ${ }^{2-3]}$. The original factory practice turned into current shorttime and random visit. Students' production practice has gradually become a mere formality and a misnomer, which glances over things hurriedly and has only a superficial understanding. There are widespread phenomena in undergraduate practice teaching which are simplified curriculum design, softening graduation design and formalized production practice ${ }^{[4]}$. Nowadays, the main problems of production practice can be described by words such as difficult, floating and partial: It' s difficult for school to find internship units; It' $s$ difficult for students to go deep into production and other links of enterprises, and the effect of practice is poor; The purposes and forms of practice deviate from the real purposes and requirements of the practice ${ }^{[5]}$. Faced with the change of social environment, the old mode of production has been difficult to cope with the new problems from new situation. University education is facing a severe challenge of improving quality, so reform is imperative ${ }^{[6-7]}$. In recent years, in the exploration of university-enterprise 
cooperation to carry out the practice teaching reform, aiming at the existing problems of practice teaching as well as the countermeasures to solve the problems, many higher education workers conducted extensive research and put forward many valuable viewpoints and methods. For example, GuoHong et al. put forward the Collegeenterprise cooperation and working-schooling combination, which is a important to achieve a doublewin effect of enterprises and universities ${ }^{[8]}$. Yi Honglei et al. put forward learning base operation mode which is based on combination involving production, teaching and research, takes enterprise technology center as a cooperation platform and establishes a comprehensive cooperation alliance between colleges and enterprises. There are good effects in practice ${ }^{[9]}$. Hui SJ et al. put forward the Order training in the actual teaching work, reflects the advantages in the clear purpose of students learning, knowledge of specific, targeted skills training and successful employments and it strengthens the close cooperation between schools and enterprises ${ }^{[10]}$. Zhang Xiu et al. discussed a mode which assimilates scientific research into teaching activities such as experiment, practice and graduation thesis. That mode uses scientific research to promote the quality of practice teaching ${ }^{[11]}$.Peng-hui Zhang put forward the wording-practice in practice teaching in the new model of collaboration education between universities and enterprises ${ }^{[12]} . \mathrm{Du} \mathrm{SJ}$ put forward government should corresponding policies and regulations to promote university-enterprise cooperation $^{[13]}$.Liu Shangwei et al. put forward the cooperation mode of production practice, innovation of scientific research and common development, which has achieved a triple-win effect of enterprises, universities and research ${ }^{[14]}$.

This paper studies and solves the problem of production practice from the angle of enterprise interests based on the theory of win-win benefit between enterprises and universities, which put forward a kind of production practice mode based on little research. It received a good effect through concrete practice.

\section{ANALYSIS ON THE WILLINGNESS OF ENTERPRISES TO ACCEPT PRODUCTION PRACTICE}

Under the market economy environment, all activities of enterprises will be considered whether profitable or not. Faced with companies not willing to receive college students production practice, the key problem of how to make enterprise receive internships at the same time obtain a benefit must be solved. Generally speaking, if students can practice more than half a year in the enterprise, the enterprise is willing to accept students' practice from cheap labor and the future labor resources and other aspects into consideration, which is the main reason why occupation school students, practice is generally welcomed by enterprises. However, operation skill training is not main purpose for undergraduate college students, so the production practice can not be arranged for a long time, and the practice can not be in a position in order to create value for the enterprise, which makes enterprises are not willing to accept the practice of college students from their own interests. Currently, college students' internship relies mainly on colleges and even personal relations to contact enterprises. The main reason for these enterprises to receive college students, production practice is maintaining the relationship between colleges and enterprises and considering attracting graduates to work in the enterprise later. If for no other reason (such as government project funding), enterprises generally do not want to arrange more in-depth production practice for college students. Thus, enterprises' coping with college students' production practice gradually evolved into such a mode: First, students are arranged for factory safety education and factory introduction. Then they visit workshops in the form of march for about two hours who don' $\mathrm{t}$ stop and don' $\mathrm{t}$ begin. Reception of production internship also gradually evolved into human resources department' s responsibility, and the people who lead students to visit the internship are often young. The consideration is to ensure the security of practice process as well as to propagandize the enterprise in order to attract students to work in the enterprise later. However, the practice effect is not very cared about. The passive cursory practice mode limits school headed internship teachers' dynamic roles. It is difficult for teachers to comment on some technical problems in live. As time passes, experienced teachers gradually fade out from the production practice, so the effects of production practice further decline.

For the mode of visit practice, there are two main enterprise' $s$ interests of receiving students' short-term production practice: First, enterprise can take the opportunity to introduce to students more comprehensive propaganda of enterprise and give students a chance to onthe-spot investigation, so that attracting excellent graduates to the enterprise in the future. Second is to establish and maintain a good relationship between the enterprises and the colleges. There are also two main adverse effects of college students' short-term production practice bring to the enterprise: one is the security liability risk of the students in the process of production practice; the second is production practice have certain interferences on the normal production of enterprises. Weigh the pros and cons, both quite, so enterprises receiving college students, production practice lacks of motivation.

\section{TO SEEK A BREAKTHROUGH IN WIN-WIN BENEFIT BETWEEN ENTERPIEISES AND UNIVERSITIES}

Production practice is an essential part of higher education, but the school does not its own practice factory, in order to complete the practical teaching process, it is necessary to find the suitable enterprise. The intention of Production practice require students to be able to go deep into the actual production of the enterprise ,to learn and understand the machine whole mass production process which from raw materials to finished, and production organization management knowledge and so on ,in order to training and establish the work style of linking theory with practice and how to verify, deepen, consolidate and enrich the theoretical knowledge. Through 
the investigation, research, analysis and solve some practical problems, students can lay a solid foundation for the follow-up professional learning, course design and graduation design. Through production practice, students will broaden the scope of knowledge, increase the perceptual knowledge, bring knowledge organization and system and learned professional knowledge that can't learn from book, it also can access to the latest information about the development of science and technology at home and abroad, to stimulate students enthusiasm to learn from practice and explore the unknown knowledge , and to lay a solid foundation for the future study and will be engaged in technical work. However, as an independent production unit, the enterprise has no obligation to provide the service to the University. In the case of the current practice teaching funds serious shortage, it is not realistic to expect the enterprise to sacrifice its own interests to help the university to complete the production practice.

How to make enterprise benefit is a breakthrough in solving the problem of production practice. In traditional production practice mode, students learn to understand the production process, technology, equipment, inspection and management of the enterprises. During the internship, they can not create value for the enterprise, so they are not welcomed by the enterprises. To fundamentally change the enterprise' $s$ attitude, it' $s$ necessary to make the enterprise benefit from the production practice. In the practice stage, college students are active in thinking who are skilled in accepting new knowledge and mastering certain professional knowledge with strong innovation practice desire. However, there are always many problems for enterprises to be solved in production technology and innovation development. If students' innovative advantages and technical requirements of the enterprise are combined, enterprise puts forward some technical requirement problems for college students to solve, so that in the production process the students study and put forward some solutions to solve the problem or ideas in order to make enterprises reap profits. Thus, it can resolve the contradictory that enterprise not welcome practice and greatly increase the effect of production practice. On the basis of the in-depth investigation, we and Wuhu Sang Lejin Electronic Technology Co. Ltd. jointly launched the practice of "innovative practice mode based on little research" to explore the mode which combine demand problems to solve with practice. After the practice of 4 classes of Grade 11 major in measurement and control, the effect is very good. The specific practices are: the enterprise studies and puts forwards a dozen practical solutions for undergraduates to solve in advance, which provide necessary conditions for the students in the factory practice. During the internship in the factory, the enterprise divides students into groups based on free topics after the collective visit, with a group of 3-5 people and each group has one topic. For each group, there is a technical personnel as a part-time teacher. The students in each group investigate actual situation of enterprise production under the guidance of a technical personnel and carry out research on practical problems to be resolved, and then submit solutions and ideas before the end of internship.
After the internship, the enterprise hosts a respondent that all the students and teachers will participate in. Each group of students reports the solution to the problem with their PPT, and the technical director proposed comment one by one. During the internship, students are innovation enthusiastic and they always go to production site with the problem, check the information, ask the teacher, burn the midnight oil to discuss issues, so they put forward many valuable ideas and solutions for the enterprise. 4 classes of Grade 11 take turns to practice in enterprises in 4 batches, and each class will come up with a new solution to the problem. For example: "intelligent air purifier system integrated design", "analysis of the sources of formaldehyde in products and the removal method ", " temperature control scheme based on heat sensitive cable " , "air duct design optimization of K4 air purifier " and " wood utilization rate calculation and control method ". These designs have received high evaluation from enterprises. After the internship, enterprises ask for funding some outstanding design schemes for subsequent research, and are willing to set up the fund of innovative practice achievement awards and accept students to do graduate design in the factory, which expand the effect of production practice further and continue to take valuable solutions in practice. This is a win-win and sustainable practice mode from which students get excellent opportunities for innovation practice and improve the effect of production practice. For enterprises, the harvests are new ideas and new solutions to solve the problem.

\section{CONCLUSIONS}

In order to solve the technical requirements of enterprises as a guide to the production practice of college students, to promote the enterprise interest needs and the aim of production practice integration, fully mobilize the enthusiasm of enterprises to support production practice and completely eliminate the root of production practice phenomenon which is void and formalization, improve the effect of College Students' production practice, it is a winwin model. Through the concrete practice, we can gain preliminary conclusions as follows:

Engineering students have a certain professional theory foundation whose enthusiasm to solve the actual problems of enterprises is very high. With the help of the instructor, it is possible for students to have some valuable ideas and design schemes that create value for the enterprise. The enterprise's power is that it is willing to accept and actively organize the production practice of the students;

In the process of production practice, college students can make full use of the enthusiasm and innovative ideas and relate theory with practice, exercise the ability to solve practical problems independently based on a comprehensive understanding of enterprise production activities, which can significantly improve the effect of production practice;

Enterprises are generally willing to actively cooperate with the school to do a good job in the production practice from their own interests, such as: to propose an appropriate number of technical problems, with a proper number of guidance teachers, to arrange practice content and the 
venue in order to entirely avoid the production internship hollowing out;

Practice guidance teachers of colleges need to do various preparatory work and organizational work, including the contact with the enterprise to determine the technical problems for students to solve and participation in research to solve technical problems during the internship.

\section{ACKNOWLEDGMENT}

This work was financially supported by Major scientific equipment development special projects:

The provincial quality project in Anhui Province of higher education, "the production practice base based on th e research of small projects" (2015sjjd002).

\section{REFERENCES}

[1] http://www.moe.gov.cn/srcsite/A08/s7056/201203/t20120316_146 673.html

[2] Zhang Huifang. Production-study-research cooperation education and the environment engineering applied talents training [J].Educational theory research, 2013, (10): 124-125.

[3] Ma Chengyu, Wang Zhaohui, Chen Xiaoguang. Research on the teaching reform of Environmental Engineering Specialty in Donghua University [J].China Education Innovation Herald,2012, (22): 45-47.

[4] Yang Lianfa, Zhou ya, Liao Weiqi. Exploration of new mode of production practice for undergraduate electromechanical Specialty [J].Higher education BBS,2010 (10) : 44-46.

[5] Duchangman. College students practice: problem analysis and solutions [J].Higher engineering education research,2010(6) : 144149 .

[6] Zhou Qifeng. Urgent need to establish long-term internship system (J).Higher education in china, 2008 (12) : 25-27.

[7] Yanchun Shen,Yinpu Zhang,Minglin Yao. The Problems of Work Placements in Application-Oriented Undergraduate Colleges and
Its Countermeasure Research [J].Communications in Computer and Information Science, 2011, 244: 1865-0929.

[8] Guohong,.Liuxiaoning Practice and Exploration of CollegeEnterprise Cooperation on Major Establishment $[\mathrm{J}]$. Communications in Computer and Information Science,2011,235:64-68.

[9] Yi Honglei, Xue Yuan, Zhang Caiyun, et al. Off-campus internship base construction based on University-enterprise cooperation alliance mode [J].Experiment technology and management,2011,28(4):139-142.

[10] Hui SJ. Exploration on Training Mode of " $3+X "$ of "Order Training" Work in Vocational Colleges [J].Advances in Intelligent Systems Research, 2010, 19:282-284.

[11] Zhang Xiu, Wang Wei, Ren Xian, et al. The construction and practice of the practice teaching mode for the research of biological engineering specialty by Scientific research [J].Experiment technology and management, 2011, 28(3):132-134.

[12] Penghui Zhang,Huali Yu,Juan Wang,et al. Advisers Troop Construction in Working-Practice in Collaboration Education Between Universities and Enterprises[J].The 19th International Conference on Industrial Engineering and Engineering Management, 2013, pp:1417-1423.

[13] $\mathrm{Du} \mathrm{SJ} \mathrm{Su} \mathrm{S}$. Inspiration of Cooperation between School and Enterprise in Germany and USA to China [J].Advances in Intelligent and Soft Computing, 2012, 135:667-672.

[14] Liu Shangwei. Exploration and practice of the mode of Productionstudy-research cooperation in engineering colleges and universities [J].Journal of North China Institute of water resources and hydropower (SOCIAL SCIENCE EDITION),2011,27(2):157-159.

The author introduce: Huang Bin, male, born in Hefei, Anhui province in November 1963, PhD, associate professor. Research direction: Mechanical Engineering.

TEL: 13856076217

E-mail: ahhb7310168@163.co 